Religare, ISSN: 19826605, v.16, n.1, agosto de 2019, p.338-369.

\title{
Música positiva católica: confusão como estratégia e o caso da banda Rosa de Saron ${ }^{1}$
}

\author{
Catholic positive music: confusion as a strategy and the case of \\ the Rosa de Saron band.
}

Leonardo Oliveira de Almeida²

\section{Resumo}

Em um contexto marcado por controvérsias, o grupo musical católico Rosa de Saron é frequentemente questionado sobre o teor ambíguo ou confuso de suas músicas. Tal fato, que para os membros do grupo pode ser compreçendido a partir de uma noção positiva de ambiguidade ou maleabilidade, surge também como elemento estratégico, pautado em uma prática musical e artística que busca legitimar-se como parte de uma das etapas do processo de evangelização, o primeiro anúncio ou querigma. Apostando no potencial de circulação dessas músicas e na multiplicidade de experiências por elas mediadas, religiosas ou não, espirituais ou ainda como "mensagem positiva", a banda transita entre a evangelização e o mercado fonográfico das majors, produzindo a "música católica que o mercado quer". Este trabalho tem como objetivo evidenciar que a banda Rosa de Saron e a popularização da "música positiva" podem lançar luz sobre as transformações na produção musical católica brasileira a partir dos anos 1990.

Palavras-chave: música positiva; confusão; querigma.

\section{Abstract}

In a context of controversy, the Catholic musical group Rosa de Saron is often asked about the ambiguous or confused content of its songs. This fact, which for group members can be understood as a positive notion of ambiguity or malleability, can also be understood as a strategic element, based on a musical and artistic practice that seeks to legitimize itself as part of one of the stages of the process of evangelization, the first announcement or kerygma. Relying on the potential circulation of these songs and the multiplicity of experiences mediated by them,

\footnotetext{
${ }^{1}$ Gostaria de agradecer aos professores Emerson Giumbelli e Rodrigo Toniol pela leitura atenta deste texto e pelos importantes comentários e sugestões.

2 Doutor em Antropologia Social pelo Programa de Pós-Graduação em Antropologia Social da Universidade Federal do Rio Grande do Sul (PPGAS - UFRGS). Pesquisador DCR - FUNCAP/CNPq no Programa de Pós-Graduação em Antropologia UFC/UNILAB. Contato: leonardoalmeida_cs@yahoo.com.br
} 
Religare, ISSN: 19826605, v.16, n.1, agosto de 2019, p.338-369.

whether religious or not, spiritual or even as a "positive message", the band floats between evangelization and the phonographic market, producing the "Catholic music that suits the market". This work aims to show that the band Rosa de Saron and the popularization of "positive music" can shed light on the transformations that have been happening in Brazilian Catholic music production since the 1990s.

Keywords: positive music; confusion; kerygma.

\section{Introdução}

O cantor Cosme e seu afrouxa (em oposição ao arrocha); as bandas de axé e swingueira do SoPraGod, Jake e Banda Dominus; Naldo José e o forró eletrônico de cristo; e a banda de rock pesado Ceremonya são alguns dos nomes da música católica contemporânea frequentemente deixados de lado pelos estudos sobre a música cristã brasileira, em parte devido à enfase dada ao segmento musical evangélico. Dentro do universo musical católico, também cabe destacar a ênfase dada aos chamados "padres cantores", movimento que ganhou força a partir da década de 1990. Soma-se a isso as recentes discussões sobre religião e espaço público, em que a música gospel evangélica vem atuando com certo protagonismo, e as discussões sobre os usos deste universo musical como "arma da cultura" (SANT'ANA, 2013; MAFRA, 2011), resultando recentemente em seu reconhecimento como "manifestação cultural". Também não devemos esquecer que a chamada cultura gospel vem ganhando maior visibilidade por acompanhar ou estar à frente das mudanças na cara da religiosidade brasileira, fato marcado pelo crescimento do número de evangélicos e o declínio do número de católicos, de forma mais acentuada, a partir da década de 1980.

Neste artigo, em contraponto, centro minha atenção na música positiva católica, expressão que designa um estilo de produção musical com enfâse em mensagens de superação, esperança e motivação, sem claras marcas confessionais e que enfatiza a perspectiva cristã em detrimento de um "cristianismo explícito", e argumento que esta vertente musical vem adquirindo popularidade a partir da convergência entre a participação no mercado musical e fonográfico, considerando sua atuação junto às 
Religare, ISSN: 19826605, v.16, n.1, agosto de 2019, p.338-369.

majors (grandes gravadoras); a influência evangélica, que pode se expressar a partir de concorrências, parcerias, afinidades e ainda certas noções de ecumenismo; e as diversas formas de experienciação da espiritualidade católica e suas transformações. Longe de ser apenas uma aplicação equivalente da música positiva por parte de católicos e evangélicos, a música positiva católica apresenta suas particularidades e aponta para as transformações nesse universo religioso. Além disso, as controvérsias em torno da música positiva estão geralmente pautadas na confusão causada pela difícil identificação confessional. Dessa forma, argumento que uma das principais estratégias de legitimação mobilizada pelos grupos musicais positivos se embasa em um duplo movimento: em primeiro lugar, compreende a evangelização cristã como um processo que possui etapas e níveis de atuação; segundo, a música positiva é considerada como pertencente às etapas iniciais da divisão do trabalho de evangelização (o que não impede que sua atuação se estenda também para as demais etapas). Em suma, torna-se pertinente analisar, a partir do caso da banda católica Rosa de Saron, algumas condições de existência da música positiva católica e suas principais características. ${ }^{3}$

Um dos impulsos mais recentes em direção a uma produção musical mais diversa foi dado entre os dias 2 a 4 de março de 2017, em Roma, com a realização do encontro Música e Igreja: culto e cultura cinquenta anos depois da Instrução Musicam Sacram $^{4}$, por iniciativa do Pontifício Conselho da Cultura e da Congregação para a Educação Católica. De acordo com a Agência Sir (Servizio Informazione Religiosa), o objetivo do evento foi “estimular uma reflexão profunda no campo musical, litúrgico, teológico e fenomenológico que possa ser uma proposta positiva por um culto cristão, expressão de louvor a Deus e prazeroso de ouvir na diversidade de modelos culturais". Durante o evento, que contou com a presença de mais de 400 pessoas,

\footnotetext{
${ }^{3}$ Os dados analisados neste texto foram obtidos a partir de documentos, sites, vídeos publicados no YouTube e entrevistas concedidas a programas de TV e canais do YouTube.

4 Trata-se de uma conferência realizada após 50 anos da publicação do documento Musicam Sacram, de 1967.
} 
Religare, ISSN: 19826605, v.16, n.1, agosto de 2019, p.338-369.

entre elas leigos e religiosos, o Papa Francisco ressaltou a necessidade de promover o "diálogo com as correntes musicais atuais, com as instâncias das diversas áreas culturais e em atitude ecumênica" ${ }^{5} \mathrm{O}$ estímulo está fortemente relacionado ao protagonismo que a musicalidade vem assumindo na contemporaneidade, não mais apenas como instrumento de mediação com o sagrado, mas também como poderoso instrumento de transformação do campo religioso.

No caso brasileiro, como alguns autores sugerem (ORO e ALVES, 2016; VICENTE, 2008a, 2008b; FERREIRA, 2013), o primeiro impulso em direção a uma musicalidade mais diversa foi dado na década de 1960, a partir do Concilio Vaticano II (1962 - 1965). O aggiornamento proposto no concílio incluía o estímulo ao ecumenismo, a abertura para novos formatos das missas e a maior participação dos leigos na Igreja, fatos que, no plano musical, resultaram também em um processo de diversificação e adoção de novas formas de evangelização e de experienciação da espiritualidade. Que "promova-se com empenho o canto popular religioso. [...] Como em certas regiões, há povos com tradição musical própria, que tem uma grande importância na sua vida religiosa e social, dê-se a esta música a devida estima e o lugar conveniente" (Sacrosanctum Concilium 118-119), assim diz um dos documentos produzidos pós-concílio.

Desde então, assistimos às transformações no campo musical católico brasileiro. Surgem as gravadoras católicas, com destaque para as gravadoras Paulinas - COMEP, criada na década de 1960, e a CODIMUC (Cooperativa de Distribuição da Música Católica), já em 1990. Nas décadas de 1970 e 1980, surgem a Canção Nova, abrindo espaço para a ampliação e diversificação da produção musical católica com sua proposta de atuação "de cima dos telhados" 6; e a Associação do

\footnotetext{
${ }^{5}$ Disponível em:

http://www.snpcultura.org/musica sacra e canto liturgico devem estar plenamente inculturadas.h $\underline{\mathrm{tml}}$

6 Parte do trecho bíblico frequentemente citados por lideranças católicas na apresentação de argumentos para a atuação midiática: "O que vos digo na escuridão, dizei-o às claras. O que vos é dito ao ouvido, publicai-o de cima dos telhados" (Mt 10,27).
} 
Religare, ISSN: 19826605, v.16, n.1, agosto de 2019, p.338-369.

Senhor Jesus, responsável pela criação do livro de cânticos Louvemos o Senhor, que, mais tarde, no final dos anos 2000, se transformou em um dos principais prêmios da música católica no Brasil, o Troféu Louvemos o Senhor. Não devemos deixar de citar também a produção musical que se popularizou entre as Comunidades Eclesiais de Base (CEBS), caracterizada por seu teor político e social e estilos musicais regionais.

Brenda Carranza (2009) situa os anos 1980 e 1990 também como o período de consolidação de um estilo de evangelização da renovação Carismática Católica através da música, reforçado nos anos 2000 a partir da intensificação de uma atuação midiática. Foi no seio dessas comunidades e grupos carismáticos que nasceram diversos cantores e bandas de projeção nacional. Podemos citar os cantores e cantoras Dunga, Adriana Arydes e Ziza Fernandes, que iniciaram sua carreira na Canção Nova; ou ainda os grupos Missionário Shalom, Davidson Silva, Alto Louvor, Suely Façanha, que tiveram o apoio da Comunidade Católica Shalom, fundada em 1982. É também nesse período, nas décadas de 1980 e 1990, que a Renovação passou a promover grandes eventos e festivais católicos. Entre eles, podemos citar o Hallel, festival de música católica que surgiu em 1988, em Franca, interior de São Paulo, e que passou a ser realizado também em outras cidades do país. Além deste, podemos citar o Halleuya, criado em 1997, pela Comunidade Shalom, e diversos outros eventos de menor porte realizados por grupos de jovens e comunidades católicas em todo o país.

Ainda 1990 as gravadoras seculares começaram a se interessar pelos cantores católicos, em especial pelos "padres cantores", que contribuíram com a consolidação do que Brenda Carranza (2011) chama de catolicismo midiático. Pe. Marcelo Rossi, provavelmente o primeiro cantor católico a assinar contrato com uma gravadora secular, é um dos principais nomes dessa geração, lançando CDs pela Universal Music (antiga Polygram) e pela Sony Music. ${ }^{7}$ Depois deste, outros padres assinaram

\footnotetext{
7 Além de Pe. Marcelo Rossi, não devemos deixar de mencionar Pe. Antônio Maria, Pe. Reginaldo Manzote, Pe. Fábio de Melo, entre outros, também alcançando grande popularidade e firmando contrato com gravadoras seculares.
} 
Religare, ISSN: 19826605, v.16, n.1, agosto de 2019, p.338-369.

contrato com grandes gravadoras, além de cantores e grupos musicais formados por leigos, tais como a banda Rosa de Saron, que em 2008 firmou sua parceria com a gravadora Som Livre.

Por fim, para concluir este breve histórico, é importante ressaltar a influência da música protestante/evangélica, que contribuiu com a diversificação dos estilos musicais católicos no período pós-Concílio. Em um de seus textos, André Florêncio, músico e missionário da Canção Nova, comenta sobre o processo de consolidação da música católica a partir da década de 1970:

Sabemos bem que há 30 ou 40 anos, início da Renovação Carismática Católica (RCC) no Brasil, havia poucas rádios católicas, poucos músicos católicos, a própria Rádio Canção Nova tocava algumas músicas evangélicas. No livro 'Louvemos o Senhor', havia algumas músicas evangélicas; outras, popularizaram-se tanto no meio católico que, hoje, ninguém imagina que são evangélicas. Músicas que, de forma alguma, ofendem ou ofenderam a nossa fé. Porém, era um tempo diferente, um cenário que justificava tais atitudes. Hoje, estamos em outro cenário, muitas coisas aconteceram na música católica em 40 anos. Há, hoje, inúmeras músicas católicas, muitos cantores, compositores etc. A Rádio Canção Nova não toca mais músicas evangélicas, já não é mais necessário tocálas. ${ }^{8}$

Tal movimento de produção musical compartilhada também é objeto de controvérsias, fato que ganhou expressividade a partir das recentes discussões da CNBB sobre o uso de músicas evangélicas durante as missas e adorações. Boa parte das justificativas apresentadas por líderes religiosos e músicos segue o argumento apresentado por André Florêncio. Nesta perspectiva, os segmentos católicos teriam alcançado um nível satisfatório de produção musical, sendo desnecessário o uso de músicas evangélicas em rituais que se baseiam em dogmas não compartilhados pelos cantores evangélicos.

\footnotetext{
8 Disponível em: https://musica.cancaonova.com/formacao-para-musicos/musica-protestante-nosencontros-catolicos-sim-ou-nao/
} 
Religare, ISSN: 19826605, v.16, n.1, agosto de 2019, p.338-369.

Estes e outros fatos contribuem para considerarmos a relação entre os segmentos musicais católico e evangélico a partir de suas múltiplas faces, flutuando entre a negação, concorrência, compartilhamento de público, formação de parcerias, iniciativas ecumênicas, influências musicais e artísticas. Como pretendo evidenciar mais adiante, tais movimentos de flutuação poderão ser observados no caso da produção musical positiva, um dos temas centrais deste artigo.

\section{Rosa de Saron}

O grupo musical Rosa de Saron foi fundado em 1988, em Campinas, por jovens da Comunidade Menino Jesus de Praga, vinculada a Renovação Carismática Católica. Seus membros são atualmente Guilherme de Sá (vocal)9 ${ }^{9}$, Eduardo Faro (guitarra), Rogério Feltrin (baixo) e Wellington Greve, o "Grevão" (bateria). Entre suas principais produções, a banda possui nove álbuns de estúdio, quatro álbuns ao vivo, quatro DVDs, além de dois livros e um documentário oficial sobre a história da banda.

Em seus primeiros anos de atuação, a banda se apresentou em festivais, concursos (muitas vezes concorrendo lado a lado com bandas seculares), grupos de oração e eventos católicos, adquirindo popularidade em São Paulo. Nesse período, o rock e o heavy metal foram os estilos musicais que mais contribuíram para a formação da identidade artística do grupo, fato que foi se modificando ao longo dos anos a partir da incorporação de novos estilos, tais como o pop e o rock romântico. Sobre a influência do Heavy Metal, Rogério Feltrin, baixista da banda, comenta que “era o que a gente curtia fazer. Mas o tempo foi passando, a gente foi mexendo, agregando novos sons, novos estilos, acrescentando coisas novas. E o amadurecimento foi acontecendo naturalmente" ${ }^{10}$. A incorporação de novos estilos,

\footnotetext{
${ }_{9}$ Guilherme de Sá deixou a banda no final de 2018 e foi substituído por Bruno Faglioni. Tal substituição aconteceu após a submissão deste artigo para publicação. Portanto, optei por manter o texto da forma original, sem as alterações referentes a substituição de vocalista, pois considero que não há perdas na consistência das análises e reflexões trazidas neste artigo.

${ }^{10}$ Entrevista concedida ao programa Balaio, em 2009. Disponível em:
} 
Religare, ISSN: 19826605, v.16, n.1, agosto de 2019, p.338-369.

bem como a associação com as majors, fato que só viria a se consolidar vinte anos após a formação do grupo, contribuíram para a ampliação do público da banda, com maior ênfase junto ao público jovem e com considerável popularidade junto ao público não religioso.

O guitarrista Eduardo Faro comenta sobre o início da banda, evidenciando tanto a pouca variedade dos estilos musicais produzidos por cantores católicos em sua época (final da década de 1980 e início da década de 1990) quanto a influência que o rock protestante/evangélico teve nesse período de anseios por uma nova diversificação musical ${ }^{11}$ :

Quando a gente começou, há muitos anos atrás, dentro da Igreja Católica não tinha nada. Era só disco de padre, quase de bolero. É verdade. E as referências que a gente teve na época são todas evangélicas. Na época era Katsbarnea, Petra, Whitecross, um material que veio de fora. A gente viu o trabalho, admirou, entendeu e pensou: nossa, a gente tem que fazer isso aqui.

Em 1994, o Rosa de Saron lançou seu primeiro CD, Diante da Cruz, pela gravadora católica CODIMUC (criada em 1990). Segundo a descrição presente no site oficial da gravadora, a banda Rosa de Saron produz "músicas numa linguagem subjetiva, mas que nos conduz à Deus e com o objetivo de atingir principalmente os jovens que estão fora da Igreja". ${ }^{12}$ A chamada "linguagem subjetiva" é apenas uma das diversas expressões utilizadas por fãs, críticos, repórteres e religiosos para designar a produção musical da banda. Em outros momentos a "linguagem subjetiva" dá lugar a expressões que apontam para certas controvérsias, tais como "música confusa", devido a sua difícil identificação confessional. O estilo musical escolhido pela banda (rock, heavy metal, pop rock) também é motivo de controvérsias. Segundo o baterista Grevão, “a reação ela vem de todos os tipos,

\footnotetext{
https://www.youtube.com/watch?v=HP2ee41m5Lc\&t=377s

${ }^{11}$ Entre os grupos evangélicos brasileiros que contribuíram para a inclusão de novos instrumentos musicais e estilos, poderíamos citar os grupos Rebanhão, Vencedores de Cristo, Grupo Logos, entre outros, que atuaram principalmente nas décadas de 1970 e 1980.

${ }^{12}$ Disponível em: http://www.codimuc.com.br/agencia/artistas/rosa de saron/
} 
Religare, ISSN: 19826605, v.16, n.1, agosto de 2019, p.338-369.

desde 'Nossa, que fantástico! Renovou!', até aquela: “Tira esse cara daqui'”. Consideremos, portanto, um espectro de opiniões diversas que atravessam o grupo.

Na década de 2000, como resultado da aceitação dentro e fora do meio religioso, o grupo despertou o interesse de gravadores seculares e, em 2008, lançou o DVD Acústico Ao Vivo, gravado e distribuído pela Som Livre. Sobre a parceria com a gravadora do grupo Globo, o guitarrista Eduardo Faro comenta a respeito do reconhecimento relativamente tardio junto ao público mais amplo e ao universo midiático:

E nesse momento, momento que vocês fecharam com uma grande gravadora, onde veio essa dimensão gigante, de Brasil, como tá sendo esse novo momento de vocês, com esse reconhecimento agora da própria mídia, e a galera agora tendo acesso a conhecer vocês?

Tá sendo emocionante pra gente. Na verdade é a realização de um sonho, porque a gente era moleque, desde os 15 anos. Eu acho que aconteceu no momento certo. Muitas vezes as pessoas falam assim: "Pô, aconteceu só vinte anos depois!". Mas eu acho que a gente precisou ter passado por tudo que a gente passou pra poder viver essa experiência. Porque hoje é difícil, é complicado, é mais profissional, mas a gente tem fé em Deus e sabe que em todos os momentos difíceis que a gente passou ele restaurou, jogou pra cima, mexeu. E hoje vai ser a mesma coisa. 13

Apesar das controvérsias e críticas à banda, diversas são as expressões de reconhecimento à importância que o grupo vem desempenhando para a evangelização católica, principalmente entre o público jovem. Em 2011, o grupo foi convidado pela CNBB a se apresentar na Jornada Mundial da Juventude, em Madri, como representante oficial da juventude católica brasileira. Além disso, os 25 prêmios recebidos no Troféu Louvemos o Senhor também anunciam o reconhecimento não apenas da banda Rosa de Saron, mas também de sua forma específica de evangelização. Em outras palavras, considero-as como expressões do

\footnotetext{
${ }^{13}$ Entrevista concedida ao programa Balaio, em 2009. Disponível em: https://www.youtube.com/watch?v=HP2ee41m5Lc\&t=377s
} 
Religare, ISSN: 19826605, v.16, n.1, agosto de 2019, p.338-369.

reconhecimento e aceitação da música positiva e das estéticas trazidas pela banda como formas legítimas de atuação junto ao público católico. Mas, tal como lembra Howard and Streck (1996), é necessário desenvolver, manter e articular raciocínios que justifiquem a existência da música cristã contemporânea em termos de valores religiosos (e católicos).

\section{A música positiva}

Eduardo Vicente (2008, p.30) aponta para o fato de que, nos últimos anos, chama atenção a busca dos segmentos católico e evangélico "por uma música que substitua o especificamente religioso - visto por ambos como fator de limitação de seu público e de seu acesso aos meios de comunicação - por 'mensagens positivas'", mensagens de superação, esperança e motivação. $O$ autor cita os casos da banda católica Shemah, vinculada à gravadora católica Paulinas-COMEP, que preferia enfatizar as "mensagens positivas", em lugar de um conteúdo que pudesse ser classificado como religioso ou evangelizador; e o caso do cantor evangélico Isabêh, que empenhou-se em incorporar, ao repertório dos grupos vinculados a sua igreja, composições que também apresentassem "mensagens positivas", que fugissem das citações religiosas, tornando-as mais aceitáveis fora do espaço da igreja. Como compreender tal movimento sem nos restringirmos ao aspecto mercadológico ou de ampliação de públicos, e ao mesmo tempo considerar as transformações no campo religioso católico? Nesse aspecto, acredito que o crescimento da renovação carismática no Brasil pode apontar para algumas condições de possibilidade da música positiva.

Para alguns autores, entre eles Pierucci e Prandi (1996), Prandi (1997) e Oro (1996), o surgimento da Renovação Carismática Católica pode ser pensada como um movimento de dupla reação, uma interna e outra externa. No primeiro caso, atuando em oposição aos movimentos progressistas católicos (Teologia da Libertação - TLC e Comunidade Eclesiais de Base - CEBS), também surgidos no período pós-Concílio 
Religare, ISSN: 19826605, v.16, n.1, agosto de 2019, p.338-369.

Vaticano II. No segundo, atuando como resposta ao rápido crescimento pentecostal e à diminuição do número de católicos. Tendo a TLC e as CEBS perdido força a partir dos anos 1990, sobretudo após as duras investidas iniciadas pelo papado de João Paulo II, para alguns autores, o pentecostalismo seria hoje o principal alvo da oposição católica.

E se, por um lado, a oposição entre catolicismo e pentecostalismo foi a chave pela qual diversos autores buscaram compreender o emergente movimento da RCC, por outro, tal como evidenciam Oro e Alves (2013), é também da RCC que surgem tentativas ou movimentos de superação dessa oposição. Os autores citam pelo menos três pontos de aproximação: em primeiro lugar, a partir das afinidades existentes entre ambos os segmentos, resultando na realização de diversos encontros ecumênicos no Brasil. ${ }^{14}$ Em segundo lugar, o político, e diz respeito à convicção sobre a necessidade de ação política direcionada às pautas consideradas como "ameaças à família", tais como aborto legal e a união civil homossexual, entre outros. Em terceiro, e o que mais interessa às discussões que se seguem, a existência de uma inserção mercadológica comum em que a música religiosa é produzida por grandes gravadoras, fomentando lucros significativos. ${ }^{15}$

Carlos Steil (2004), Carranza (2009), Oro e Alves (2016), entre outros autores, vêm evidenciando as proximidades entre a Renovação Carismática e o pentecostalismo. Entre algumas dessas semelhanças, tal como afirma Sofiatti (2009, p. 219), a RCC vem propondo "uma experiência pessoal e íntima de comunicação com Deus", ou ainda, segundo Faustino Teixeira (2005, p. 20), uma "experimentação religiosa, que enfatiza o contato direto e íntimo com Deus". Brenda Carranza (2011, p. 23) também chama atenção para uma proposta que "se aproximava da sociedade

14 Em trabalho posterior, Oro e Alves (2016) também evidenciam movimentos de recusa do ecumenismo, partido da Renovação Carismática, na tentativa de pôr em prática regimes de diferenciação e delimitação de fronteiras entre católicos e pentecostais.

${ }^{15}$ Como exemplo a Universal Music, que lançou trabalhos com Padre Antônio Maria e Padre Marcelo Rossi; a Sony Music com Padre Zezinho, Padre Marcelo Rossi, Padre Fábio de Melo, Padre Alessandro Campos (o Padre Sertanejo); a Som Livre com Reginaldo Manzoti, Celina Borges, Adriana Arydes, Bando Dominus, Rosa de Saron, entre outras. 
Religare, ISSN: 19826605, v.16, n.1, agosto de 2019, p.338-369.

por meio da atuação pessoal fundada numa religiosidade emotiva [...]". Reginaldo Prandi e Renan Santos (2015, p. 365), por sua vez, na tentativa de expor as transformações religiosas vivenciadas no Brasil a partir da década de 1980, consideram o papel exercido pela Renovação Carismática e pela Teologia da Libertação (em um contexto de crescimento do primeiro e retração do segundo) afirmando que "agora, no lugar do coletivo, da assembleia, da organização popular, outro sujeito toma assento, ou melhor, recupera sua antiga posição: o indivíduo. A Igreja abandona o grupo organizado para a ação no mundo social e político e passa a se interessar tão somente pela pessoa, pelo indivíduo [...]". Soma-se a isso a ênfase na cura e na libertação, marcada também pelo caráter emotivo, e a utilização de práticas mágicas.

Aqui encontramos uma importante ponte entre as transformações nas formas de vivenciar a espiritualidade e a produção musical cristã. Selene Ferreira (2013) narra as transformações na música cristã brasileira a partir de uma perspectiva que põe em evidência certas tendências em que "a figura de Deus é colocada próxima ao homem, como amigo, alguém que está junto, e temos assim uma construção que não era muito comum na música sacra". Ainda segundo a autora, tal fato colabora para as controvérsias e críticas advindas de algumas instâncias da Igreja Católica e, inclusive, de alguns artistas. "Trata-se do fato das músicas estarem cada vez mais voltadas para o 'eu', para um individualismo, uma relação pessoal e individual do fiel com o divino" (FERREIRA, 2013, p. 40). Um dos principais críticos dessa perspectiva, cita autora, é uma dos principais nomes da música católica brasileira, Pe. Zezinho, que afirma:

Eu chamaria a atenção para o fato de que, por enquanto, de cada 20 canções que se compõe no Brasil, evangélica e católica, 19 são de louvor, só uma é social. Isso é fraco! [...] Só diz “Eu te louvarei, louvarei, louvarei, louvarei". Falta o outro. [...] Se tem tanto talento assim, pega um livro, estuda, faz música sobre a cruz do povo, sobre a dor do povo. [...] É tudo limpador de para-brisa. Tá faltando dor do povo. Eu, se tivesse uma autoridade... Eu não tenho, mas, se tivesse, eu diria: 
Religare, ISSN: 19826605, v.16, n.1, agosto de 2019, p.338-369.

Compositores, façam música sobre os problemas do povo também, não só sobre o louvor. ${ }^{16}$

Este se torna um momento propício para fazer algumas considerações sobre a música positiva, uma vez que esta se caracteriza como uma produção musical que contém letras que enfatizam o indivíduo e seus dilemas, propondo superação e esperança a partir de perspectivas cristãs em detrimento de um cristianismo explícito.

As duas músicas a seguir podem ser consideradas como tendo "mensagens positivas", pois, segundo os membros da banda Rosa de Saron, inspiram confiança, esperança, perseverança. Apesar de não falarem diretamente sobre Deus, apresentam uma "perspectiva cristã":

Cai o dia, tarde escura, acho que vai chover

Eu que sempre me escondi do mundo,

hoje talvez queira sair

Descobri outros ares

Acho que preciso me encontrar

Se é sonho ou real, não importa

Eu preciso sentir e assim talvez

Eu encontre o meu lugar, lugar

E mesmo que eu perca o horizonte

Estarei na esperança de que um dia alguém

Quem sabe alguém

Me ajude a ver onde errei
O vento bate na janela

Eu busco asas pra voar

Pra bem mais perto de Você

Bem mais perto de Você

Estamos livres mas sozinhos, abandonados

Por quem tinha que nos entender

Por quem tinha que nos defender

Hoje muitos choram mas não desistem de viver

Hoje muitos choram sorrindo Hoje muitos choram mas não desistem de viver

Hoje muitos choram sorrindo

Como afirmam Haward e Steck (1998), esse tipo de conteúdo, presente nos grupos integrais ${ }^{17}$, reflete as ideias de Denisoff (1972) sobre "música de protesto",

\footnotetext{
${ }^{16}$ Entrevista concedida ao programa No ritmo da fé, da Rádio Catedral FM, em 04 de dezembro de 2010.

${ }_{17}$ Os grupos integrais são apresentados pelos autores como uma das tipologias que apontam para diferentes relações entre Cristo e a cultura (o mundo). Para que consigam obter a atenção do mundo, os grupos integrais devem se tornar respeitáveis pelos padrões do mundo (culturais). O tema será abordado novamente mais adiante.
} 
Religare, ISSN: 19826605, v.16, n.1, agosto de 2019, p.338-369.

música que enfatiza seu aspecto lírico ou intelectual, tentando convencer o ouvinte de que algo está errado e de que há a necessidade ou a possibilidade de alteração. Ela é projetada para "converter" o ouvinte para uma nova perspectiva que exige uma resposta. Canta-se que estamos livres, mas sozinhos, abandonados por quem tinha que nos entender e nos defender. "Hoje muitos choram", mas, apesar disso, "não desistem de viver". E também: "Acho que preciso me encontrar. E mesmo que eu perca o horizonte, estarei na esperança de que um dia alguém, quem sabe alguém, me ajude a ver onde errei".

As músicas descrevem desafios, apresentam questões, bem como apresentam uma perspectiva que, ao fim, pede respostas. Constrói-se a carência por soluções. Algumas dessas respostas podem ser as próprias "mensagens positivas", outras são deixadas para que o espectador as encontre ou complemente: "quem sabe alguém me ajude a ver onde errei".

Em entrevista para o Baú do Rodeio na TV, em 2016, novamente o guitarrista da banda, Eduardo Faro, comenta:

\section{É legal que Rosa de Saron faz uma música falando de Deus, mas que pode usar também pra um romance bonito, uma coisa legal, mas falando de Deus. Tá atingindo vários públicos. Inclusive no show você vê um público jovem. Como você vê que a música de vocês tá tocando no coração, no sentimento dos jovens?}

A grande proposta nossa não é só tentar ficar enfiando Deus goela abaixo das pessoas. A gente vive aqui nosso cotidiano, passa as dificuldades que todo mundo passa. É tentar passar uma mensagem positiva, de esperança, que funciona pra todo mundo. Todo mundo tem solidão, todo mundo tem tristeza, todo mundo também tem seu momento de... Lá que a namorada deu um biquinho em você, que você tá triste. $\mathrm{E}$ as pessoas acabam se identificando porque é tudo muito sincero. $\mathrm{E}$ como é feito pra todo mundo, não só as pessoas que tão participando de comunidade [comunidade religiosa], as pessoas se identificam, gostam, tem utilizado pra se ajudar nos momentos difíceis. Então vem todo mundo misturado lá [nos shows], vai ter muita coisa legal lá. 
Religare, ISSN: 19826605, v.16, n.1, agosto de 2019, p.338-369.

Retomando discussões anteriores, tanto as semelhanças quanto os movimentos de superação de oposições entre católicos e pentecostais puderam, em diversos contextos, se expressar a partir da existência de um público comum. Outro caminho possível tem sido os usos da noção de cultura ${ }^{18}$, muitas vezes utilizada com ênfase em seu potencial de entretenimento. Um bom exemplo disso foi a realização de uma das edições da Festa do Peão de Barretos, que incluiu em sua programação um dia destinado a shows de grupos musicais cristãos. Em 2009, o primeiro ano que contou com a participação de cantores gospel, o mesmo palco foi utilizado pela banda católica Rosa de Saron e pelos cantores evangélicos André Valadão e Mattos Nascimento. André Valadão, por exemplo, comentou sobre sua presença no evento afirmando: “A música gospel é cultura! É positiva e traz uma reflexão espiritual na vida das pessoas" ${ }^{19}$

Ao compartilharem um público comum, alguns grupos musicais católicos e evangélicos utilizam certos elementos e práticas que venham a "funcionar" para ambos os segmentos cristãos, também buscando reduzir ou apagar as características estéticas ou doutrinárias que venham a limitar o alcance de suas músicas. Como exemplo, evitam letras que falem sobre Nossa Senhora, ou que tenham como tema central a adoração ao Santíssimo Sacramento, práticas não compartilhadas pelo público evangélico. Em comentário publicado no YouTube, junto ao vídeo de uma das músicas da banda Rosa de Saron, um fã escreve: “Eu sou católico e gosto de todas as letras do Rosa. Não existe nelas nada que venha a separar nós de nossos irmãos evangélicos, a música é para todos, é nossa liberdade de expressão, de adorarmos a Deus e exaltarmos o seu nome. Que vocês continuem sempre assim

\footnotetext{
18 Ver Mafra, 2011.

19 Entrevista concedida ao site gospelmais.com.br, em 2009. Disponível em: https://noticias.gospelmais.com.br/andre-valadao-fara-o-primeiro-show-gospel-da-maior-festa-depeao-do-brasil.html
} 
Religare, ISSN: 19826605, v.16, n.1, agosto de 2019, p.338-369.

Evangelizando através da Música". Outro fã, durante um show da banda em Belo Horizonte, comenta: "Serve pra todo tipo de religião". ${ }^{20}$

\section{Música Confusa}

Mas as palavras "redução" e "apagamento" não parecem suficientes para nossa reflexão. Característica marcante nos usos dessas estratégias de aproximação e consolidação de um público comum são as controvérsias decorrentes do que alguns autores abordam a partir da ideia de confusão. Romanowski (2000, p. 105) nos dá o exemplo da cantora gospel Amy Grant:

In order for Christian artists to be successful outside the evangelical Market, gospel companies had to cooperate with secular ones, blurring boundaries between religious and secular both in cultural perception and in industrial reality. Codistribution deals let evangelical artists "cross over" onto the mainstream charts, but with songs "about life experience without any hidden spiritual agenda," as Amy Grant said about her Heart in Motion album. The crossover music confused evangelical consumers; there was seemingly nothing to distinguish Christian music from its secular counterpart.

O tema da confusão no campo da religião já foi objeto de estudo de alguns autores (ENGELKE, 2012, 2013; MEYER, 2006; HISCHKIND, 2006), e frequentemente esteve acompanhado de discussões sobre a presença do religioso no espaço público. Em um dos casos analisados por Matthew Engelke $(2012,2013)^{21}$, as discussões sobre secularismo, ecumenismo e sobre a presença da religião no espaço público estiveram presentes na elaboração da decoração de natal em um shopping na cidade de Swindon, Inglaterra. Na ocasião, a Sociedade Bíblica buscava propor uma decoração de natal que suprisse os interesses ecumênicos do grupo, além trazer à tona

\footnotetext{
${ }^{20}$ Entrevistas concedidas ao programa Balaio, em 2009. Disponível em: https://www.youtube.com/watch?v=HP2ee41m5Lc\&t=377s

${ }_{21}$ Engelke $(2012,2013)$ busca compreender "como o público é público" a partir dos trabalhos realizados pela Sociedade Bíblica na Inglaterra. Para Engelke, não é suficiente afirmar que uma religião é pública, é preciso investigar suas condições de publicidade, daí uma de suas questões centrais: "How public is public?".
} 
Religare, ISSN: 19826605, v.16, n.1, agosto de 2019, p.338-369.

estratégias que visavam alcançar os mais diversos públicos, inclusive o público não religioso. Como solução, a Sociedade Bíblica decidiu utilizar anjos em formato de pipa, acreditando em sua capacidade de estimular a imaginação, inspirando uma experiência espiritual (mas não religiosa). Para a Sociedade Bíblica, a presença dos anjos não faria parte de nenhuma "religião pública", sendo possível, inclusive, conseguir a aprovação do Conselho local antes do início do processo de decoração do shopping. Os anjos, portanto, transmitiriam uma "mensagem religiosa travestida de espiritualidade" (GIUMBELLI, 2016, p. 329).

Engelke ressalta o impacto material dos anjos, contribuindo para compor uma "fé ambiente" no shopping e fornecendo um sensual register que muitas vezes serve para confundir a coerência da divisão público/privado. Ao passo que poderiam ser "apenas anjos", capazes de atiçar a imaginação e a espiritualidade sem indicadores explícitos de um caráter religioso, para algumas pessoas eles também poderiam ser objeto claro de experiências religiosas. Dessa forma, como afirma Engelke, os anjos "fornecem um convite ao espectador para preencher o espaço em branco, para apropriar-se do objeto em sua própria vida ou história. Como objetos, então, os anjos eram feixes semióticos de determinada indeterminação" (ENGELKE, 2012, p. 160, tradução minha). Para que não pareçam expressões materiais de uma religião pública, portanto, os anjos foram elaborados para confundir a coerência da divisão religioso/não religioso.

A análise de Engelke lança luz sobre os casos analisados neste trabalho em pelo menos três aspectos. Primeiro, de que forma a confusão é utilizada e justificada, possibilitando diferentes regimes de atuação e eficácia? Segundo, ao analisar a noção de espiritualidade, Engelke nos aponta de que forma certos elementos permitem a passagem entre usos e sentidos distintos. Torna-se válido, portanto, identificarmos quais elementos distorcem a coerência entre o religioso e o não religioso. Por fim, a atenção que é dada aos impactos materiais e as experiências daí decorrentes. Nesse aspecto, torna-se importante discernir como certos objetos (as músicas, por exemplo) atuam e são postos em prática de forma a alcançar os objetivos propostos pelo grupo. 
Religare, ISSN: 19826605, v.16, n.1, agosto de 2019, p.338-369.

No caso da banda Rosa de Saron, a confusão se expressou, por exemplo, quando o grupo foi recebida no programa Encontro, transmitido pela Rede Globo e apresentado por Fátima Bernardes, da seguinte forma:

O Rodrigo (um dos convidados do programa) falou que conheceu vocês pela internet e que custou perceber que era uma banda católica. (Fátima Bernardes)

Isso que é o bacana. Porque pra muita gente que não gosta de religião, você vai lá, apresenta: "Rosa de Saron. Escuta aqui, é católico". "Ah... não quero". A gente tem muito caso curioso. "Ouve essa banda aqui". "Mas é religioso? Mas é legal". (Guilherme de Sá) ${ }^{22}$

A confusão aqui se expressa a partir da dificuldade de distinguir entre um grupo musical secular e um grupo musical religioso. Segundo o vocalista Guilherme de Sá, tal indefinição pode ser compreendida como um ponto positivo das músicas do grupo, um meio pelo qual barreiras que poderiam impedir sua circulação e utilização em diferentes espaços são ofuscadas. Em consonância com esta afirmação, em trabalho recente sobre a cantora católica Jake, Evandro Bonfim (2015) afirma que trabalhar com a simples hipótese de que é cada vez mais tênue (ou mesmo inexistente) a linha que separa os empreendimentos sagrados daqueles seculares significa adotar a perspectiva de observadores externos ao circuito de produção, divulgação e recepção de conteúdos religiosos, desconsiderando como os próprios emissários concebem (no sentido de refletir sobre e criar) as mensagens que transmitem. O uso da confusão pela banda Rosa de Saron pode ser compreendida por um duplo viés: se por um lado, a confusão é utilizada para contribuir com a ampliação dos espaços de atuação das músicas do grupo, por outro, também é cuidadosamente conduzida a ser eficaz. Aos poucos, a confusão vai adquirindo um teor estratégico. Longe de ser uma ação despretensiosa, a banda desenvolveu ao longo dos quase trinta anos de carreira uma produção musical capaz de ocupar

\footnotetext{
22 Entrevista realizada em 2014, Rede Globo.
} 
Religare, ISSN: 19826605, v.16, n.1, agosto de 2019, p.338-369.

diferentes espaços, a partir de uma atuação musical e performática que consegue transitar entre a confusão e a eficácia.

\section{Música querigmática}

Resta incluirmos na discussão o papel do mercado musical junto à proposta da música positiva. Nesse aspecto, o caso da cantora gospel norte-americana Amy Grant é emblemático. Como lembra Romanowski (2000), as grandes gravadoras começaram a se interessar pela música cristã quando, em 1982, Amy Grant alcança a marca de um milhão de cópias vendidas no mercado gospel com seu disco Age to Age, mesmo sem o apoio da grande mídia. A partir de então, a empresa A\&M firma parceria com a gravadora de Grant, WORD, ampliando ainda mais o alcance de suas músicas. O próximo passo foi a progressiva tentativa de ampliação do público, adaptando as letras cristãs para que chegasse a novos espaços. Como afirma Grant, "There are a lot of songs that I just write and the only differentiation between them and secular pop music that I would say is that they are an observation of everyday life from a Christian perspective" (MILLARD, 1986, p. 155). Após o lançamento do primeiro álbum produzido a partir da parceria A\&M/WORD, em 1985, Grant amplia sua carreira, chegando a ser a primeira cantora gospel a alcançar o topo da Bilboard Hot 100, em abril de 1991.

Haward e Streck $(1996,2015)$, ao analisarem o que chamam de música cristã contemporânea (CCM), defendem a necessidade de vê-la como um mundo artístico fragmentado que opera com base em três conjuntos de racionalidades diferentes que, por sua vez, são baseados em suposições básicas sobre o relacionamento adequado entre Cristo e a cultura. Para tanto, discorrem sobre a música cristã contemporânea a partir de três modelos: Separational, Integrational e Transformational. No modelo integracional, os autores evidenciam grupos musicais que, para buscarem obter a atenção do mundo, devem se tornar respeitáveis pelos padrões do mundo, ao contrário do modelo separacional, que propõe uma separação entre cristo e a cultura 
Religare, ISSN: 19826605, v.16, n.1, agosto de 2019, p.338-369.

(o mundo). No processo de obtenção dessa respeitabilidade, podem perder a sua distinção. O grande medo, portanto, é de o mundo transformá-los antes que possam transformar o mundo. Os autores ainda afirmam que este foi o caso da música cristã contemporânea integrativa, sendo sua música transformada de mensagens descaradamente cristãs para o "pop positivo" que, em sua maior parte, aborda o valor do indivíduo e a importância do amor.

Esse movimento, de valorização mercadológica da música positiva, vem acompanhado de constantes controvérsias, o que obriga as bandas e cantores a construírem suas justificativas e seus meios de legitimação, que podem variar conforme o estilo musical adotado, grupo religioso do qual se originou, o tipo de público que pretende ser atingido, a relação com os diferentes tipos de gravadoras (gravadoras católicas, gravadoras independentes ou majors), entre outros.

No caso da banda Rosa de Saron, o desligamento da gravadora católica CODIMUC e o subsequente contrato com a gravadora Som Livre evidenciam duas características sobre a produção musical do grupo. Primeiro, o reconhecimento dos potenciais do Rosa de Saron para atuar em diferentes espaços, não apenas religiosos. Segundo, a popularidade que a "música positiva" vem adquirindo nos últimos anos. Ambos os aspectos, tal como venho argumentando, apontam para a reconfiguração da espiritualidade católica, sobretudo a partir do crescimento da Renovação Carismática e de uma espiritualidade com ênfase na experiência pessoal do indivíduo. Com isso quero afirmar que a valorização e legitimação da música positiva no meio católico podem estar fortemente relacionadas às transformações na espiritualidade católica no Brasil, principalmente pela influência carismática, a partir da década de 1990.

Avancemos então mais um passo. Segundo o guitarrista da banda Rosa de Saron, Eduardo Faro, em entrevista ${ }^{23}$ ao programa Academia do Som, da TV católica Canção Nova, há uma íntima relação entre a música querigmática produzida pela

\footnotetext{
${ }^{23}$ Entrevista concedida em 2009. Disponível em: https://www.youtube.com/watch?v=c7RBmYi ZYs
} 
Religare, ISSN: 19826605, v.16, n.1, agosto de 2019, p.338-369.

banda Rosa de Saron e sua aceitação no mercado. O guitarrista nos fornece uma justificativa em termos teológicos para a relação entre a música religiosa e o mercado. Na questão a seguir, o entrevistador do programa parte da distinção entre o mercado religioso (Cristo) e o mercado pop (cultura), sendo a noção de querigma apresentado posteriormente por Eduardo como o elemento que promove acomodações entre os dois universos.

\section{Eu gostaria de saber se nunca houve a vontade de sair do mercado religioso pra conquistar o mercado pop?}

A gente sempre foi uma banda de primeiro anúncio, desde o início. Você pode ver que o tipo de linguagem que a gente usa nas letras, são linguagens... É mais amplo. Não é só pra quem tá dentro da igreja. Não é música de louvor e adoração, tem uma ou outra, mas são músicas de evangelização querigmáticas. Por causa dessa filosofia das letras, ela tem uma aceitação muito fora da igreja. Pessoal tem muita carência de letra legal. Já comentaram em vários lugares que a gente foi: "Pô, hoje a música tá muito voltada pra entretenimento, axé e tal. Faltava música falando de vida, de saudade, de esperança". Tem muita gente carente no mundo. Muita gente de fora se identificou. $\mathrm{O}$ mercado quer levar essa música religiosa pra festas de rodeios, pra festas de peão, pra festas de cidade. Então as vezes o pessoal pode achar que a gente tá querendo sair do mercado [religioso]. Não é. É a banda católica, é a música católica que o mercado quer.

Ao evidenciar sua atuação querigmática, ou seja, a proposta de ter uma atuação voltada para o primeiro anúncio, a banda Rosa de Saron também realiza um convite à aceitação diante das controvérsias, pautado na utilização de um recurso já há muito presente no repertório católico: a noção de querigma. Para os membros da banda, portanto, é preciso que o público religioso compreenda o tipo de estratégia empregada, ou seja, a atuação em uma das etapas na divisão do trabalho religioso de evangelização, “o primeiro anúncio de Jesus Cristo, feito de modo simples, mas caloroso e envolvente" (Francisco e Rodrigues, 2012).

É importante considerar que as noções como "modo simples" ou "primeiro anúncio", elementos que configuram a ideia de querigma, transformam-se ao longo do tempo e adquirem contornos distintos, dependendo do contexto onde são 
Religare, ISSN: 19826605, v.16, n.1, agosto de 2019, p.338-369.

empregadas. Isso nos coloca diante de novos questionamentos sobre as transformações no campo religioso brasileiro: por quais transformações passaram as noções de "modo simples", "primeiro anúncio" e "querigma" ao longo dos últimos anos? No caso da banda Rosa de Saron, é possível afirmar que a noção de modo simples, enquanto estratégia legítima, passou a incluir estéticas do rock e da música positiva e, de forma não menos importante, a confusão. A noção de querigma aparece aqui, portanto, como importante instrumento para a compreensão de fronteiras, pondo em discussão as diferentes definições de música religiosa e de música secular, os diferentes modos de aproximação entre Cristo e a cultura, além da necessidade de se incluir ou não a dimensão confessional no momento do primeiro anuncio.

A fala do guitarrista Eduardo Faro também evidencia ser este "o tipo de música católica que o mercado quer", momento em que discurso religioso e mercadológico se alinham. Ainda na mesma entrevista, o baixista Rogério Feltrin responde a mesma questão:

Mercadologicamente é logico que você acaba se expandindo. Hoje a gente atinge o público fora do religioso... Atinge um público evangélico muito forte. Mas sempre com a nossa identidade como católico. Agora a minha fé não interfere que a minha música chegue às pessoas que pensam ou professam fé diferentes da minha. A gente não tem intenção, nunca teve, e vai continuar sendo o mesmo estilo de banda, se Deus abençoar, continuar pra sempre assim. Mas a gente quer cada vez chegar a um público mais diferente.

Em outra entrevista, fornecida ao blog Viciados em Rosa de Saron ${ }^{24}$, o baixista também comenta: "No sentido mercadológico, quanto mais o trabalho estiver infiltrado em outros meios além do católico, melhor. Não temos medo nenhum disso". Estas são algumas expressões da intencionalidade por trás da produção de uma musicalidade que se quer alinhada com o mercado das majors e, ao mesmo

\footnotetext{
${ }^{24}$ Entrevista concedida em 2010. Disponível em: http://www.viciadosemrosadesaron.blogspot.nl/2010/10/entrevista-com-rosa-de-saron-rogerio.html
} 
Religare, ISSN: 19826605, v.16, n.1, agosto de 2019, p.338-369.

tempo, alinhada com os desejos do público religioso, estando estes fortemente relacionados às formas já citadas de experienciação da espiritualidade.

A banda parece tentar convencer seu público religioso de que a produção musical em questão não está pautada em um esvaziamento do conteúdo cristão. Trata-se, por outro lado, de um método ou estratégia, uma das formas possíveis de atuação, e que pode ser considerada como uma das etapas do processo de evangelização. Ao evidenciar etapas, a banda posiciona-se, leva em consideração os outros grupos musicais que contribuem para oferecer outras estratégias e propostas de evangelização. Somada à redução dos indicadores religiosos, a divisão do processo de evangelização em etapas e entre distintos agentes parece incluir a produção musical positiva de católicos e evangélicos em um mesmo trabalho evangelizador (que se expressa também pelo compartilhamento de público), sendo essa uma das dimensões da proposta ecumênica.

Por fim, passemos a outro elemento peculiar e que também gera discussões no meio católico desde os primeiros anos após a formação da banda. Parte dessas controvérsias advém da presença de um vocabulário pouco comum no meio religioso, sobretudo quando está em questão um suposto diálogo entre o fiel e Deus, elemento já evidenciado anteriormente, colocando o público em uma possível situação de indefinição e ambiguidade. As letras a seguir pertencem respectivamente às músicas Sem Você, Meu Abandono e Ninguém Mais, sendo a primeira delas uma das mais famosas da banda, tendo alcançado, em 2009, o primeiro lugar na lista das 100 músicas mais ouvidas do site Kboing, tirando da primeira colocação a música Borboletas da dupla sertaneja Vitor e Léo. 
Religare, ISSN: 19826605, v.16, n.1, agosto de 2019, p.338-369.

\begin{tabular}{|c|c|}
\hline Minha vida, minha história & 1,2,3, testando, ei, alô som \\
Só fez sentido, quando Te conheci & Você é tudo pra mim \\
Seus olhos, Sua (sagrada) face, & As vezes fico assim um pouco bobo \\
Me levam além do que pensei & mas não ligo é tudo pra mim \\
Tudo, tudo, tudo pra mim \\
Se às vezes me escondo em Você, me \\
acho, \\
Algo simples, quero algo simples \\
como versos que um dia fiz, \\
que o vento espalhou e trouxe o seu \\
sorriso disfarçar \\
Não há como explicar \\
Foi sem Você que eu pude entender \\
Que não é fácil viver sem Te ter \\
Meu coração me diz que não \\
É Tudo, tudo, tudo pra mim. \\
Isso basta!
\end{tabular}

\begin{tabular}{|c|}
\hline Não há nada igual \\
Nada poderia me afastar de Ti \\
Não, não há alguém que me faça \\
tão bem como você faz \\
E nunca haverá \\
Me transforme no melhor que \\
posso ser \\
Não há fim, não há volta \\
Porque só quem pode preencher o \\
meu vazio é você \\
Você, ninguém mais
\end{tabular}

Expressões comuns às músicas católicas, tais como "Tu és", "Vós", "Senhor", "Meu Deus", "Jesus", não estão presentes aqui. Quem seria o Você das músicas em questão? Para muitos fãs fora do meio religioso, as músicas podem ser compreendidas como um diálogo entre um casal de namorados. Por esse motivo, a banda Rosa de Sarom é novamente questionada sobre os múltiplos usos de suas músicas e a suposta falta de clareza com relação ao enquadramento religioso. 
Religare, ISSN: 19826605, v.16, n.1, agosto de 2019, p.338-369.

Diversos vídeos publicados no YouTube trazem as três músicas apresentadas anteriormente, acompanhadas da letra e de algumas imagens. ${ }^{25}$

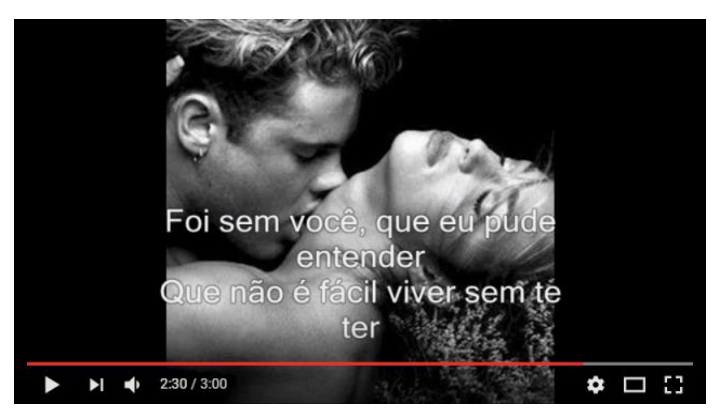

Imagem 1: Frame. Fonte: YouTube

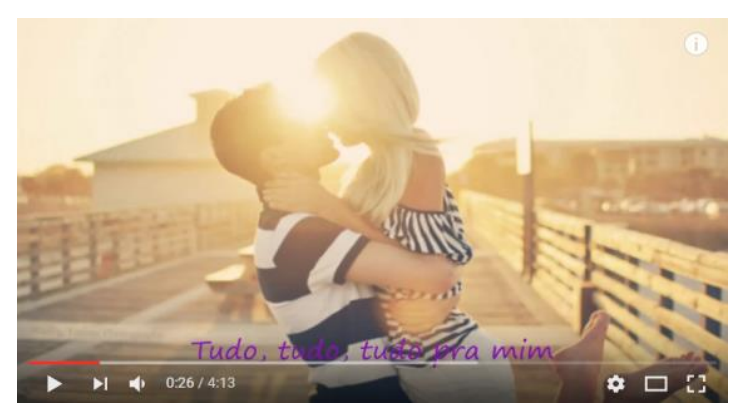

Imagem 2: Frame. Fonte: YouTube

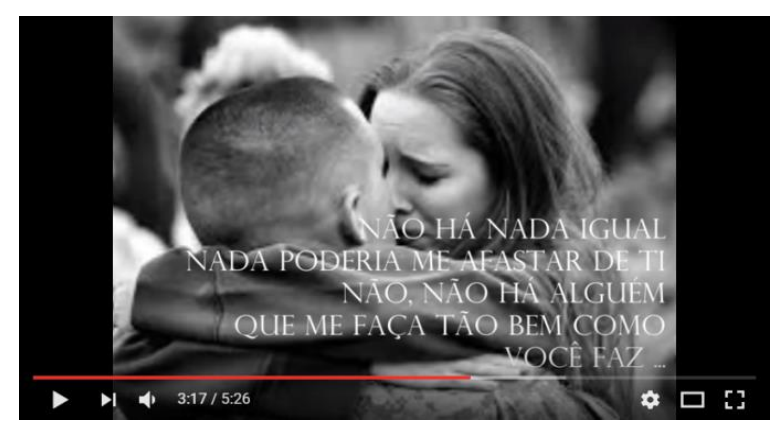

Imagem 3: Frame. Fonte: YouTube

Geralmente feitos para e por casais, os vídeos estão comumente acompanhados de comentários do tipo: “Essa música parece minha e do meu exnamorado quando eu vim pra cá escutei muito essa música agente estava muito distante um do outro...". Para outros, faz lembrar um parente ou um amigo falecido: "Sempre choro quando escuto essa música por que o meu avo morreu e passei o natal sem ele q ele foi pro hospital e no ano novo ele morreu".

Em contraposição, outros comentadores buscam alertar aos demais leitores e aos responsáveis pela publicação dos vídeos sobre seu sentido primeiro, o religioso.

“Música lindíssima.... Declaração de amor à Jesus Cristo, pois só Ele dá sentido em nossa vida, só Ele quem faz muita falta e realmente.....não é Fácil viver sem ter Jesus. Muitos podem

\footnotetext{
${ }^{25}$ Laís Ferreira (2013, p.12) cita o caso semelhante da banda evangélica Oficina G3: "Um ponto forte da questão poética desta canção é o fato de sua letra não citar o nome de Deus, [...] sua letra pode levar o ouvinte a uma interpretação romântica. Em linhas gerais, a letra aborda questões subjetivas de sentimentos que podem ser entendidos tanto como uma relação do homem com Deus quanto uma relação entre homem e mulher”.
} 
Religare, ISSN: 19826605, v.16, n.1, agosto de 2019, p.338-369.

conhecer Jesus, mas só aqueles que o experimentam sentem sua Falta.".

“Essa música não é pra ficar lembrando de ex-namorado e tal, ela fala do amor de Jesus com a gente".

“Essa música não foi feita para cantar pra mulher nenhuma, essa música foi feita pra Jesus Cristo pra quem entende é um amor verdadeiro, sem você, Jesus eu não consigo viver".

Quais elementos, portanto, confundem a coerência da divisão entre o religioso e o não religioso? No site oficial da banda, em uma das publicações em que os integrantes fazem breves comentários sobre as faixas do CD O Agora e o Eterno, são abordados os incômodos gerados pelos usos que comumente são feitos das músicas fora do contexto religioso. Sobre a música Maquina do tempo, foi feito o seguinte comentário:

Por anos, devido à subjetividade (grifo meu) das canções do Rosa de Saron, muitos se sentiam mal quando outras pessoas usavam as canções da banda fora do contexto religioso. Isso nunca foi um problema para os integrantes, nunca será um problema cantar o amor. É uma questão de opção. A letra de Máquina do Tempo é um poema de amor e apenas isto. É uma letra criada para ser cantada de um amor para o outro, sem medo de errar.

Em outra entrevista, concedida ao canal do YouTube Vibe Rosariana ${ }^{26}$, em 2009, o vocalista Guilherme de Sá também comentou: “Os nossos amores são sempre voltados pra Deus e a gente sempre abriu mão de que pessoas falassem pros namorados. O amor é lindo, cara, esquece. Entendeu? A gente não é mais aquele bando de moleque bitolado, que ou é isso ou não é isso". Rogério Feltrin, em entrevista retirada da página oficial do grupo Vibe Rosariana no Youtube, grupo formado por fãs da banda, responde a pergunta dos fãs sobre a ambiguidade das letras das músicas e sua recepção.

\footnotetext{
${ }^{26}$ Entrevista disponível em:

https://www.youtube.com/results?search query=Vibe+Rosariana+saco+de+perguntas
} 
Religare, ISSN: 19826605, v.16, n.1, agosto de 2019, p.338-369.

Como eles [os membros da banda] reagem ao saber que
muitas pessoas usam as suas músicas para fazerem
declarações de amor para namorados, amigos, sendo que
foram criadas para retratar o amor por Deus?

Afinal, o amor é divino. Acho que tá respondido.

Tal como foi evidenciado por Engelke sobre a noção de espiritualidade, o amor seria o elemento que muitas vezes confunde a coerência das divisões entre o religioso e o não religioso. Assim como a positividade e a noção de querigma, o amor permite passagens, pois são intencionalmente apresentados como feixes de determinada indeterminação (ENGELKE, 2012), fornecendo ao espectador um convite para preencher o espaço em branco, para apropriar-se do objeto com sua própria vida ou história. Ao apropriarem-se, acreditam os membros da banda, também são apropriadas as perspectivas cristãs. Podemos pensar a noção de querigma, em uma de suas faces contemporâneas, como sugestão de perspectivas cristãs (sem delimitações claras quanto à denominação religiosa).

Mas devemos lembrar que ao propor uma atuação querigmática, a banda Rosa de Saron propõe aos fãs insatisfeitos com os usos não religiosos de suas músicas um movimento que vai da confusão como objeto de incomodo à confusão como objeto estratégico. Sobre esse último aspecto, outro fã comenta sobre os vídeos citados anteriormente:

\footnotetext{
“Essa música é muito linda e tocante! Seja pra quem for que esteja cantando, pode ser pra mulher que ama, pra algum ente querido que já se faleceu, pra qualquer pessoa que q gente ama, ou até mesmo pra Deus, Nosso Senhor Jesus Cristo, falando do amor a Deus... O fato é que essa música é uma das mais tocantes que existe, me arrepio todas as vezes que escuto e nas primeiras vezes que ouvi até chorei!"
}

Ao atuarem feixes de determinada indeterminação, as músicas devem contar com regimes diversos de circulação. Distribuídas em aparelhos de MP3, celulares, YouTube, reuniões de grupos de oração, sites de letras de músicas, festas de rodeio, missas, eventos ecumênicos, as músicas adquirem usos diversos. Por outro lado, a banda conta com algumas possibilidades de adaptação, indicando formas de 
Religare, ISSN: 19826605, v.16, n.1, agosto de 2019, p.338-369.

experienciação. Como exemplo, a músicas Sem Você, citadas anteriormente, é frequentemente submetida a certas adaptações em performances ao vivo. Durante uma das adorações ao Santíssimo Sacramento, ocorrida no evento católico Hallel, em Maringá (2011) 27, a expressão "sua face", presente na letra original (gravação de estúdio), foi substituída por "sua sagrada face". Em outro trecho, a expressão "sem você" foi substituída por "sem você, meu senhor". ${ }^{28}$ Com o tempo, os complementos e ajustes feitos pela banda passaram a ser amplamente conhecidos pelos fãs religiosos, formando-se uma espécie de segunda versão "oficial", frequentemente performatizada em coro durante as apresentações ao vivo. Por outro lado, na Festa do Peão de Barretos (2009) ou no programa Encontro da TV Globo (2016), eventos sem caráter claramente religioso, a música Sem Você foi executada da forma original (gravação de estúdio). Com isso não pretendo afirmar que a banda Rosa de Saron objetiva negar ou esconder qualquer indicador religioso durante as performances executadas em ambientes seculares. Minha intenção é evidenciar que o grupo explora regimes de maleabilidade, adaptação e eficácia, produzindo uma musicalidade que permite a existência de formas distintas de experienciar a "perspectiva cristã".

\section{Considerações finais}

Considero que a valorização da música positiva no meio católico e, de certa forma, o sucesso tardio da banda Rosa de Saron (tal como evidenciado pelo guitarrista Eduardo Faro, citado anteriormente) possuem forte relação com a “revalorização da intimidade sacralizada do indivíduo" (PRANDI, 2015, p. 365), fato que adquiriu contornos específicos a partir do crescimento da Renovação Carismática e do processo de "carismatização" de grupos e movimentos católicos nos últimos anos. Dessa forma, não podemos afirmar que apenas o motor mercadológico

\footnotetext{
${ }^{27}$ Disponível em: https://www.youtube.com/watch?v=hoNRJCO9NL0

${ }^{28}$ Ver quadro anterior.
} 
Religare, ISSN: 19826605, v.16, n.1, agosto de 2019, p.338-369.

possibilitou a popularização da conveniente música positiva e a consolidação de um público comum entre católicos e evangélicos, mas também certas proximidades quanto às formas de experienciação da espiritualidade.

A música positiva, portanto, com sua preferência pela perspectiva cristã em detrimento do cristianismo explícito, parece atuar como uma espécie de cavalo de troia, capaz de adentrar despercebida em alguns espaços, propondo certas perspectivas e experiências. Esta também remete ora a uma linguagem ecumênica, pautada no compartilhamento de público e pela atração de apreciadores não religiosos, ora como uma linguagem com claras intenções proselitistas, capaz de afirmar-se católica e ao mesmo tempo distinguir-se de outras denominações cristãs. No contexto brasileiro, a música positiva expressa sua conveniência em tempos de um catolicismo que deixou de atuar como único fornecedor no mercado religioso dos bens de salvação.

Tais afirmações não têm por objetivo desconsiderar os diversos elementos que contribuem para a popularidade da banda Rosa de Saron dentro e fora do universo católico, elementos estes que não são meramente acessórios à proposta da música positiva. São também de grande importância a incorporação de elementos da música pop ao longo da carreira da banda, a atuação midiática que conta com o apoio das majors, as estéticas e performances que, em grande medida, atraem um público jovem, entre outros.

Seria a valorização da música positiva uma das formas assumidas pela proposta de uma produção musical ecumênica? Seria esta, a música positiva, também uma das formas assumidas por uma espiritualidade afinada com as linguagens pentecostais e carismáticas, que se aproximam da sociedade "por meio da atuação pessoal fundada numa religiosidade emotiva" (CARRANZA, 2011, p.23), com ênfase na cura e libertação? Ou ainda um estilo de produção musical eficaz no resgate de fieis católicos (que abandonaram o catolicismo ou "os que ainda não foram") justamente pela possibilidade de adaptar-se a diferentes regimes de intenção (ou diferentes fases do processo de evangelização)? Seria essa uma música que se 
Religare, ISSN: 19826605, v.16, n.1, agosto de 2019, p.338-369.

caracteriza por ser "a música católica que o mercado quer", capaz de atrair o apoio da mídia secular? Enquanto feixes semióticos de determinada indeterminação, a música positiva pode chegar ao campo do entretenimento sem esbarrar no religioso e, ao mesmo tempo, chegar ao campo entretenimento passando pelo religioso? A música positiva católica, portanto, assume tantas formas quanto vêm assumindo a sociedade brasileira, porém em diálogo com o que Pierucci (2006) já apontava sobre o pluralismo religioso brasileiro retratado no Censo de 2000: quase binário. O quadro se confirma no Censo de 2010, uma vez que a parcela cristã chega a $86,8 \%$ das declarações de pertença religiosa.

Julgo pertinente considerar a atuação do rock positivo a partir da afirmativa de Marcelo Camurça (2014, p. 78) sobre a produção de híbridos na sociedade brasileira. Segundo o autor, no "calor do momento" após a divulgação dos dados do Censo de 2010, "cada vez mais as religiões no Brasil se intercalam no tecido social/cultural produzindo híbridos como 'mercado religioso', 'turismo religioso', 'atletas de Cristo', 'padres e pastores-cantores', 'bancadas evangélicas' etc'. Incluo a música positiva produzida pela banda Rosa de Saron como pertencente a esse processo de produção de híbridos, porém com a possibilidade de transitar em diferentes regimes de hibridização. Não por acaso, tal como busquei apresentar ao longo deste artigo, a banda consegue transitar entre o rock romântico sem claros vínculos religiosos (mas ainda considerando a possibilidade de propor perspectivas cristãs) e o papel de representante da juventude católica brasileira, a convite da CNBB, na Jornada Mundial da Juventude.

Por fim, reforço a noção de "evangelização querigmática", ou "primeiro anúncio", como importante instrumento analítico. Se considerarmos que o "primeiro anúncio" pode assumir formas distintas, sujeitas a conjunturas e intencionalidades diversas, torna-se pertinente questionar de que forma este recurso vem sendo utilizado em diálogo com as transformações no campo religioso brasileiro. A música da banda Rosa de Saron nos mostra como a proposta de evangelização querigmática, uma justificativa religiosa para uma proposta de produção musical específica, pode 
Religare, ISSN: 19826605, v.16, n.1, agosto de 2019, p.338-369.

assumir formas que permitem transições entre o mais e o menos confessional, entre o cristianismo explícito e a sútil perspectiva cristã.

\section{Referências}

CARRANZA, Brenda. Perspectivas da neopentecostalização católica. In CARRANZA, Brenda et. all. (orgs.) Novas comunidades católicas: em busca do espaço pós-moderno. AparecidaSP: Idéias \& Letras, 2009.

. Catolicismo midiático. Idéias \& Letras, 2011.

CAMURÇA, Marcelo. A.“O Brasil religioso que emerge do Censo de 2010: consolidações, tendências e perplexidades". In: Teixeira, F \& Menezes, R. (orgs.). Religiões em movimento: o Censo de 2010. Petrópolis, Rio de Janeiro: Vozes, 2014.

DENISOFF, R.S. Sing a Song of Social Significance. Popular Press, 1972.

ENGELKE, Matthew. Angels in Swindon: Public religion and ambient faith in England. American Ethnologist, v. 39, n. 1, p. 155-170, 2012.

. God's agents: Biblical publicity in contemporary England. Univ of California Press, 2013.

FERREIRA, Laís Cândida. O rock e a cultura evangélica juvenil: música \& identidades. Revista Eletrônica História em Reflexão, v. 7, n. 14, 2013.

FERREIRA, Selene. Das igrejas para os palcos: O mercado da música católicaApropriações e ressignificações. Tese de Doutorado. Dissertação (Mestrado em Comunicação), Niterói, Universidade Federal Fluminense, 2013.

FRANCISCO, Me Fernando Rodrigues; RODRIGUES, Maurilio Alves. Os leigos na obra conciliar do Vaticano II e nas conferências episcopais latino-americanas. Revista de Cultura Teológica, n. 79, p. 127-147, 2012.

GIUMBELLI, Emerson. Publicamente cristãos. Religião e Sociedade, Rio de Janeiro, 36(2): 327-332, 2016.

HOWARD, Jay R.; STRECK, John M. The splintered art world of Contemporary Christian Music. Popular Music, v. 15, n. 1, p. 37-53, 1996.

. Apostles of rock: The splintered world of contemporary Christian music. University Press of Kentucky, 2015.

HIRSCHKIND, Charles. The Ethical Soundscape: Cassette Sermons and Islamic Counterpublics. New York: Columbia University Press, 2006.

MAFRA, Clara. A "arma da cultura" e os "universalismos parciais". Mana, Rio de Janeiro, v. 17, n. 3, Dec. 2011.

MEYER, Birgit. Religious Sensations: Why Media, Aesthetics and Power Matter in the Study of Contemporary Religion. Inaugural Lecture, Free University of Amsterdam, 2006.

MILLARD, B. Amy Grant: A Biography. Doubleday,1986.

ORO, Ari Pedro; ALVES, Daniel. Renovação Carismática Católica: movimento de superação da oposição entre catolicismo e pentecostalismo?. Religião $\mathcal{E}$ sociedade. Rio de Janeiro, RJ. Vol. 33, n. 1 (2013), p. 122-144, 2013. 
Religare, ISSN: 19826605, v.16, n.1, agosto de 2019, p.338-369.

ORO, Ari Pedro; ALVES, Daniel. Renovação Carismática Católica e pentecostalismo evangélico: convergências e divergências. Debates do NER. Porto Alegre, RS. Vol. 17, n. 30 (jul/dez. 2016), p.[219]-245, 2016.

PRANDI, Reginaldo. Um sopro do Espírito. São Paulo: Edusp, 1997.

PIERUCCI, Antônio Flávio. Cadê a nossa diversidade religiosa? In: TEIXEIRA, Faustino e MENEZES, Renata (orgs.). As Religiões no Brasil: continuidades e rupturas. Petropolis: Vozes, pp. 49-51, 2006.

PIERUCCI, Antônio Flávio e PRANDI, Reginaldo. A realidade social das religiões no Brasil. São Paulo: Hucitec, 1996.

ROMANOWSKI, William D. Evangelicals and popular music: The contemporary Christian music industry. In: FORBES, Bruce David; MAHAN, Jeffrey H. Religion and popular culture in America. University of California Press, 2000.

SANT'ANA, Raquel. A música gospel e os usos da "arma da cultura". Reflexões sobre as implicações de uma emenda. Revista Intratextos, v. 5, n. 1, p. 23-41, 2014.

SANTOS, Renan William dos; PRANDI, Reginaldo. Mudança religiosa na sociedade secularizada: o Brasil 50 anos após o Concílio Vaticano II. Revista Semestral do Departamento e do Programa de Pós-Graduação em Sociologia da UFSCar, v. 5, n. 2, p. 351, 2015.

SOUZA, André Ricardo de. Igreja in concert: padres cantores, mídia e marketing. Annablume, 2005.

SOFIATI, Flávio Munhoz. Elementos sócio-históricos da renovação carismática católica. Estudos de Religião, v. 23, n. 37, p. 217-241, 2009.

STEIL, Carlos Alberto. Renovação Carismática Católica: porta de entrada ou de saída do catolicismo? Uma etnografia do Grupo São José, Porto Alegre (RS). Religião $\mathcal{E}$ Sociedade, v. 24, n. 1, p. 11-36, 2004.

TEIXEIRA, Faustino. Faces do catolicismo brasileiro contemporâneo. Revista Usp, n. 67, p. 14-23, 2005.

VICENTE, Eduardo. A Música Católica no País. A Atuação da Gravadora Paulus. Anais do XXXI Congresso Brasileiro de Ciências da Comunicação - Natal, RN, 2008a.

- Música e Fé: A cena religiosa no mercado fonográfico brasileiro. Latin American Music Review, v. 29, n. 1, p. 29-42, 2008 b.

Recebido em:16/10/2018

Aprovado em:17/09/2019 